\title{
Ecosystem management: Implications and opportunities of a new paradigm ${ }^{1}$
}

\author{
by Carlos Galindo-Leal ${ }^{2}$ and Fred L. Bunnell ${ }^{3}$
}

Resource management is undergoing a shift in paradigms (Kessler 1992; Kessler et al. 1992; Franklin 1994; Rowe 1994). A paradigm is "an implicit theory or conceptual framework from which other theories or understandings derive their validity" (O'Donnell 1990); within science a paradigm provides researchers with model problems and solutions (Kuhn 1970). Advances in our understanding of how ecosystems function combined with changes in society's expectations are rapidly changing the way we perceive, study, and manage our resources. Contributions from the relatively new, and broadly integrative, fields of landscape ecology and conservation biology emphasize the importance of spatial context in planning and managing (Crow 1990; Bunnell and Kremsater 1994). Management emphasis is on the maintenance of large, dynamic systems. Central to this shift in paradigm is the concept of "ecosystem management". The term is increasingly being used by scientists, managers, policy makers and the general public, but not always with the same meaning (Johnson and Agee 1988; Salwasser 1988, 1992; Joyce 1992; Scientific Panel for Sustainable Forest Practices in Clayoquot Sound [CSP] 1994; Grumbine 1994; Franklin 1994). Several authors provide historical reviews of the concept's development from different perspectives (Franklin 1994; Grumbine 1994; Jensen and Everett 1994). In this paper we examine the development of the concept, its implications, and the opportunities within a Canadian context.

Key words: Ecosystem management, conservation biology, landscape ecology, forest management
La gestion des resources connaît actuellement un changement de paradigmes (Kessler 1992; Kessler et al. 1992; Franklin 1994; Rowe 1994). Un paradigme est "une théorie implicite ou un cadre de travail conceptuel à partir duquel d'autres théories ou concepts éprouvés obtiennent leur validité" (O'Donnell 1990); dans le domaine scientifique, un paradigme procure aux chercheurs des problèmes modèles et des solutions (Kuhn 1970). Les progrès dans notre compréhension du fonctionnement des écosystèmes combiné aux changements dans les attentes de la société modifient rapidement la façon dont nous percevons, étudions et gérons nos ressources. Les contributions des domaines relativement nouveaux, et grandement intégrants, de l'écologie des paysages et de la biologie de la conservation mettent l'emphase sur l'importance du contexte spatial dans la planification et la gestion (Crow 1990; Bunnell et Kremsater 1994). La gestion met l'emphase sur le maintien de systèmes importants et dynamiques. Au centre de ce changement de paradigme réside le concept de "gestion écosystémique". Le terme est de plus en plus utilisé par les chercheurs, les gestionnaires, les concepteurs de politiques, et par le public en général, mais pas toujours avec la même signification (Johnson et Agee 1988; Salwasser 1988; Joyce 1992; Scientific Panel for Sustainable Forest Practices in Clayoquot Sound [CSP] 1994; Grumine 1994; Franklin 1994). Certains auteurs ont effectué des révisions historiques du développement du concept selon différentes perspectives (Franklin 1994; Grumbine 1994; Jensen et Everett 1994). Dans cet article nous examinons le développement du concept ses implications et les possibilités au sein du contexte canadien.

Mots clés: gestion écosystémique, biologie de la conservation, écologie des paysages, gestion forestière.

\section{Introduction}

Forests and wildlife management have been planned traditionally for short temporal and small spatial scales. For example, forest practices have focused on the stand level and been planned for five-year intervals. Although forestry practitioners have long appreciated that some issues such as harvest scheduling, watershed management, or visual quality required thoughtful analysis of actual spatial distribution, few effective tools were available for such analysis or planning (Bunnell 1992). There are, however, important long term and large scale consequences of cumulative, short term management decisions (Nelson and Finn 1991; Nelson et al. 1991; Daust and bunnell 1994; Galindo-Leal 1994). Integrative

\footnotetext{
${ }^{1}$ This contribution is part of the B.C. Hydro project "Conservation of Biodiversity: a research framework for Mica Wildlife Compensation Program (Kootenay Region)"; it is publication M-3 of the Centre for Applied Conservation Biology.

${ }^{2}$ Tropical Research Program, Center for Conservation Biology, Department of Biological Sciences, Stanford University, Stanford, California USA 94395-5020.

${ }^{3}$ Centre for Applied Conservation Biology, Faculty of Forestry, 2357 Main Mall University of British Columbia, Vancouver, British Columbia, V6T-1Z4.
}

planning tools that do not evaluate consequences of forest harvest in real space are misleading; real space matters. That is particularly true of the recent management charge to maintain forest biodiversity (Bunnell and Kremsater 1990, 1994). Theorists have assumed that the temporal and spatial scale of management should be based upon natural disturbance regimes and spatial requirements of organisms (White and Pickett 1985; Bunnell 1992; Hunter 1993); recent evidence supports that assumption (Bunnell 1995b). At these scales there are many unanswered questions which require research (Bunnell 1992; Bunnell and Kremsater 1994). Large scale and long term research necessitates a distinctive approach which takes advantage of management activities and the close collaboration of scientists and managers from a variety of agencies.

Globally, events in the tropics first stimulated attention to large spatial scales and biodiversity. In North America, research on grizzly bears in Yellowstone National Park during the 1970s most clearly revealed the need for a different approach to maintain wide-ranging species (Grumbine 1994). A much smaller species, however, unequivocally grasped the forest managers' attention - the spotted owl. Below, some steps are briefly reviewed in the dramatic shift from single-species approaches to a multi-species, ecosystem approach. 


\section{A Brief History}

The northern spotted owl (Strix occidentalis caurina) exemplifies the shift dramatically and has become a symbol of oldgrowth dependent species from northern California to British Columbia. The bird possesses several characteristics that make it sensitive to changes in its habitat (Gould 1977; Forsman et al. 1980). In most of their range, spotted owls do best in large areas of old-growth forest and do not breed until they are three years old. Juvenile survival is low. Much of the mortality has been attributed to their inability to disperse through inhospitable habitat created by logging (Carey 1985; Grumbine 1992). There is an estimated 3500 pairs of owls from northern California to southern British Columbia. Populations have been declining at $1-2 \% \mathrm{yr}^{-1}$, apparently due to old-growth harvesting and fragmentation (Salwasser 1988). In the United States, over $90 \%$ of the remaining suitable habitat of spotted owl is on public lands (Grumbine 1992); in Canada, the percentage is still higher.

In 1984 the first Northern Spotted Owl Management Plan by the U.S. Forest Service was released. The agency proposed to set aside 400 ha of old-growth for each of 263 pairs of owls (Wilcove 1989). New data, however, soon suggested such provision to be well short of the owls' requirements in some areas (Wilcove 1989; Grumbine 1992). About this time, the management of spotted owls and their habitat became rich in controversy, with committees, panels, law suits, court injunctions, and logging bans, and the history is well documented. Although the story is ongoing, Grumbine (1992) provides a good review.

While great attention and effort was focussed on the spotted owl, more species of the American Pacific Northwest were being proposed for listing under the U.S. Endangered Species Act, including gray wolf, grizzly bear, peregrine falcon, bald eagle, marbled murrelets, Sacramento river chinook salmon, Snake river sockeye salmon, Mexican spotted owl, northern goshawk, and McDonald's rock cress (Grumbine 1992; Forest Ecosystem Management Assessment Team [FEMAT] 1993). The rich and troubled history of management efforts for the spotted owl case made it clear that a species by species approach to conservation was not efficient. In the United States, the Scientific Panel on Late-Successional Forest Ecosystems was created (1991) to go beyond a single-species approach and to address a regional reserve system. The panel's mandate was to develop protection alternatives for ecologically-significant, old-growth and late successional ecosystems, species, and processes. At the same time it developed guidelines for management of unreserved lands (Grumbine 1992). This new panel concluded that plans for the conservation of the spotted owl would do little to protect ecosystem functioning and other old-growth species. FEMAT was formed and charged with identifying forest management options that would attain the greatest economic and social contribution from the forests while meeting requirements of applicable laws and regulations (e.g. U.S. Endangered Species Act, National Forest Management Act, National Environmental policy Act) (FEMAT 1993).

Canada followed these footsteps, but at a more rapid pace. The Canadian Spotted Owl Recovery Team was formed in 1990. Before it had prepared its recovery plan (to be based on apparent ecological requirements of the species), it was redirected to preparing an "Options Report" that placed it firmly in the nexus of economic and ecological concerns. By late 1992 the Recovery Team had begun considering implications to other species within spotted owl range, but society, never stagnant, was already moving the goal posts. The government of British
Columbia had responded to societal concerns and implemented, or participated in the creation of, a Protected Areas Strategy, various Biodiversity Guidelines, a new Forest Practices Code, and a Marbled Murrelet Recovery Team - each within the range of the spotted owl. Again real space had become important and a species-by-species approach was clearly inefficient.

Nor was the rest of the world quiet. The Brundtland Commission of 1987 focussed world attention on environmental concerns and offered the concept of sustainable development to express a balance between economic and ecological concerns. The Commission never addressed the concept of biological diversity, nor used the term "biodiversity". Within five years several major international agreements were signed at the United Nations Conference on Environment and Development (UNCED '92) or "Earth Summit" at Rio de Janeiro. Four of these directly or indirectly addressed the concept of biodiversity in forested systems.

The Convention on Biological Diversity, signed by more than 160 nations and ratified by more than 30 (thus in force as a treaty) contains three major national obligations: (1) to conserve biological diversity, (2) to use biological resources in a sustainable manner, and (3) to share benefits of biodiversity fairly and equitably. Agenda 21 addresses the conservation and rational use of forests and the conservation of biological diversity. The Framework Convention on Climate Change, signed by 150 countries (and now ratified by more than 90), includes as goals the promotion of sustainable management, and the promotion of the conservation and enhancement of carbon sinks and reservois (i.e. forests, wetlands). Finally, the Guiding Principles on Forests includes relevant elements such as the integration of forest management with adjacent areas to maintain ecological balance and sustainable productivity. Specific content or implications of these agreements have been published in The Forestry Chronicle (For. Chron. (1992) 68: 424-426; 433-434; see also Boyle (1992) and Johnston (1993)).

Three factors ensured that Canada participated actively in the creation of these agreements: (1) wide-spread public concern about forest practices, (2) the dominating role that export of forest products plays in the Canadian balance of trade, and (3) Canada's vulnerability to "green consumerism". Canada is signatory to all four agreements and played an important role in guiding their content (Johnston 1993; CSP 1995a). Nonetheless, the pace with which global instruments dealing with biodiversity in forested systems were created was cyclonic, and public concerns rapidly outstripped managers' experience in meeting them. Some new approach was needed.

In North America, the United States responded first, stimulated by events surrounding the spotted owl. During the late 1980 s, the U.S. Forest Service established new directions for enhancing ecosystem research (Kessler et al. 1992). This approach, known as "New Perspectives", included changing roles for management, public participation, and science. Soon after, the U.S. Forest Service adopted the paradigm of "Ecosystem Management" (Kaufmann et al. 1994; Franklin 1994). Canadian forestry practitioners were likewise having to encompass a wider range of objectives (Burton et al. 1992; Bunnell 1992; Slocombe 1993). The Canadian Council for Forest Ministers (CCFM) formulated its first national strategy in 1987 ; it is now all but forgotten. The new strategy, formulated in 1992, Sustainable Forestry - a Canadian Commitment outlines more than 90 action items and defines sustainability as 
to maintain and enhance the long-term health of our forest ecosystems, for the benefit of all living things both nationally and globally, while providing environmental, economic, social and cultural opportunities for the benefit of present and future generations.

The Draft Canadian Biodiversity Strategy was circulated by the Canadian Biodiversity Convention Office in June 1994. Each of these strategies and other initiatives, such as the Natural Forest Landscape (NFL) (Booth et al. 1993), are based on the principle of ecological sustainability. All approaches at least implicitly recognize the importance of managing ecosystems at multiple spatial and temporal scales (Bunnell 1992; Galindo-Leal 1994).

British Columbia is both the most vulnerable province in Canada to "green consumerism" and home to the most persistent, and costly public demonstrations regarding forest practices. The province also has embarked on major initiatives embraced by the concept of ecosystem management. These include creation of a new Forest Practices Code (FPC), the Commission on Resources and Environment (CORE), a comprehensive Protected Areas Strategy (PAS), creation of Biodiversity Guidelines and Field books, and the Scientific Panel for Sustainable Forest Practices in Clayoquot Sound (CSP). This latter group has defined an approach to sustainable ecosystem management, and is developing operational standards for its implementation (CSP 1994, 1995b).

While there is a clear trend toward a more integrated regional approach, the term "ecosystem management" is often used in different ways.

\section{What is Ecosystem Management?}

In the past decade, several agencies involved in land-use planning and management have indicated the need for a shift to ecosystem management or landscape management (Johnson and Agee 1988; Salwasser 1988, 1992; Joyce 1992; CSP 1994). To a great extent concerns underlying ecosystem management and maintenance of biodiversity are the same. The international agreements that emerged from UNCED ' 92 often assume implicitly that more holistic (or ecosystem) management will help to maintain biodiversity. Both of these concepts are still evolving (Bunnell 1992, 1995a; Joyce 1992; Grumbine 1994). Like biodiversity, the term ecosystem management, suffers from reification, the presentation of an abstract idea as if it were a thing (Bunnell 1995a). That is apparent in our attempts at definition; for example:

Regulation of internal ecosystem structure and function, plus inputs and outputs, to achieve socially desirable conditions. Interagency coordination is a key element of successful ecosystem management (Johnson and Agee 1988).

A strategy or plan to manage ecosystems to provide for all associated organisms, as opposed to a strategy or plan for managing individual species (FEMAT 1993).

Any land-management system that seeks to protect viable populations of all native species, perpetuate natural-disturbance regimes on the regional scale, adopt a planning timeline of centuries, and allow human use at levels that do not result in longterm ecological degradation (Grumbine 1992).
Integrates scientific knowledge of ecological relationships within a complex sociopolitical and values framework toward the general goal of protecting native ecosystem integrity over the long term (Grumbine 1994).

CSP (1994) explicitly recognized ecosystem management as a complex process and provides a several-page description of the process rather than a concise definition.

These definitions are necessarily general and serve primarily to characterize an approach that differs from an earlier approach (Bunnell 1995a). For forested systems, this earlier approach is perceived to be the dominance of one kind of product when management objectives are formulated (CSP 1994). Commonalties, nonetheless, emerge from the definitions. Because ecosystem management is more clearly an abstract idea than a thing, these commonalities are best treated as implications to management actions.

\section{Implications of Ecosystem Management}

Just as in ecosystems themselves, the major parts or implications of ecosystem management are not neatly discrete. We can, however, determine seven broad ones that are more clearly separable (Table 1). It is telling that all of these implications are addressed directly in the international agreements emerging for UNCED '92, noted above.

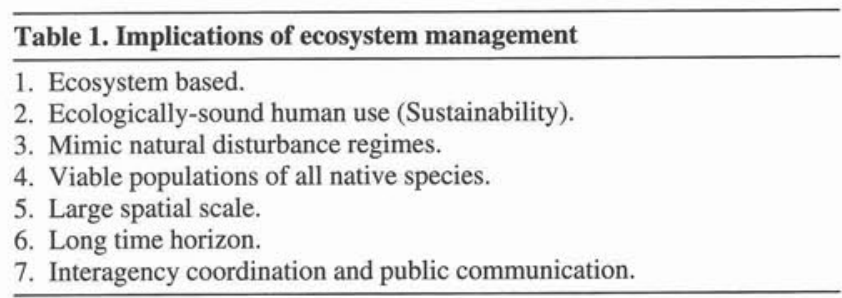

\section{Ecosystem Based}

There are many definitions of the term "ecosystem". In most discussions of ecosystem management, the definition considered is simple: an area where plants and animals (including humans), and micro-organisms interact with each other and with their environment (Joyce 1992; CSP 1994). Originally, the ecosystem concept was dimensionally undefined (Waring 1989) and emphasis was on processes and connections. In this new context, processes remain important, but it is at the least implicit that the area is large (on the order of 200 to $500 \mathrm{~km}^{2}$ ), heterogeneous and open.

Efforts to make ecosystem management a workable concept have recognized the units should have natural boundaries, meaningful to important processes, such as watersheds or collections of watersheds (CSP 1994). Often the term "landscape" is used interchangeably with ecosystem (i.e. landscape management). Landscape is defined as a mosaic of contiguous ecosystems (Joyce 1992), but would be more workable if it directly and explicitly acknowledged landform boundaries. Landform boundaries change very slowly; because ecosystems include mobile components that can and do move among specific places, specifying management targets around ecosystem components can prove frustratingly difficult.

The recent emphasis on ecosystem level approach differs dramatically from the earlier ecosystem approach of the International 
Biological Program. The recent approach includes an important spatial dimension founded in concepts of landscape ecology and conservation biology (Bourgeron and Jensen 1994). The earlier approach was firmly based on nutrient and energy cycles and on small spatial scales. Clearly, both local energy flux or nutrient cycles and large scale horizontal flows of water and nutrients are important.

\section{Ecologically Sound Human Use (Sustainability)}

Ecosystem management is based on the concept of sustainability. Humans are acknowledged as important ecosystem components whose values influence the direction of natural processes (UNCED '92 agreements) (CSP 1994). Management is to address the needs of the present without compromising the ability of future generations to meet their own needs (e.g. CCFM National Strategy). Long term productivity, resilience to stress, adaptability to change and options for the future should be considered (Maini 1992; Salwasser 1992). The many services and values provided by ecosystems should not be compromised. The processes captured by the term "ecosystem" are to be retained and to function within their natural ranges (CSP 1994). Biodiversity enters directly because the term implicitly or explicitly (depending on the definition) includes both ecological services and resources.

Placing humans directly into the ecosystem acknowledges both important social dimensions to the process and the fact that management actions will occur. Adaptive management is an appropriate framework within which to learn and modify management practices accordingly (Kessler et al. 1992; Joyce 1992; FEMAT 1993; Halbert 1993; CSP 1995b). Using such a framework, management practices should be designed as experiments complete with controls and replicates. Monitoring and responding to results of management interventions are a priority within, this framework, but face formidable social and institutional barriers (Lee 1993).

\section{Mimic Natural Disturbance Regimes}

Landscapes are mosaics of patches (Wiens 1989). In the absence of disturbance, landscape mosaics are determined by abiotic factors such as soil type, productivity, topography, temperature, humidity, etc. Disturbances, however, are a fact of life in all environments, and landscapes exhibit a dynamic, shifting mosaic in time and space (Wiens 1989; Bunnell 1992). Variations in the frequency, extent, and magnitude of disturbances produce complex patterns in the composition, age-structure, and size distribution of patches in these mosaics. Different species also vary in their responses to disturbances.

Large scale management activities (e.g. agriculture, grazing, damming, logging) modify the composition and structure of the landscape, influencing species in different ways (e.g. reduction of forest-interior species, increase in the density or occurrence of edge species, disruption of migratory routes) (Galindo-Leal 1994). A number of authors have suggested that the best approach to maintain native biodiversity is to imitate natural disturbance regimes (Noss 1992; Hansen et al. 1993; Hunter 1993). Bunnell (1995b) provides analyses for forested ecosystems that support the suggestion. Natural disturbances in ecological systems are complex and include an array of characteristics such as spatial distribution, frequency, return interval, rotation period, predictability, area, magnitude, severity, and synergisms that have to be considered (Wiens 1989). For these reasons, and the fact that biodiversity encompasses an enormous range of species, efforts to express targets for forest ecosystem management have invoked patterns produced by natural aisturbance regimes (CSP 1994, 1995b; Bunnell 1995a). Those efforts make the assumption that appropriate elements of form and function will be sustained within a range of disturbance that approximates the natural range.

\section{Viable Populations of All Native Species}

It is here that the connections of ecosystem management with biodiversity noted earlier are most direct. There are three important implications of this connection. First, viability is the ability to persist over a long period. It implies centuries rather than years or decades (Salwasser 1988). Second, the unit of concern is generally populations, but genetic variability and processes are, at the least, implicit. The role of populations implies the need to understand population dynamics, population trends, and to consider the natural range of populations and their genetic variability, and not to focus solely on species diversity. The difference between existence (presence) and persistence (viable population) must be recognized (Ruggiero 1991). Third, ecosystem management implies the consideration of the full complement of species. Because it is impossible to provide guidelines species by species, a different approach is required (Salwasser 1988; Bunnell et al. 1991: Williams and Marcot 1991).

\section{Large Spatial Scale}

The necessity of large spatial scales flows from the preceding points. The requirement to maintain natural processes intact, the concept of mimicking natural disturbances, the maintenance of wide-ranging populations, and the recognition that planning for sustainable use must be hierarchical — all require consideration of large areas. In such planning, real space matters and appropriate tools are just being developed (Nelson and Finn 1991; Daust and Bunnell 1994). In fact, the commitment to biodiversity requires planning over several scales (Bunnell 1992; Bunnell and Kremsater 1994) including a full consideration of the regional context (Franklin 1994; CSP 1995b).

To date most management practices (e.g. timber harvesting, wildlife management) do not include a regional analysis. Relations between protected areas and adjacent managed habitats are reciprocal; each influences the effectiveness and consequences of the other. That is especially true of large scale habitat modification due to forest practices (Galindo-Leal 1994). The landscape mosaic has to be considered including areas of 50 to $1000 \mathrm{~km}$ (Bunnell and Kremsater 1990, 1994).

\section{Long Time Horizon}

The time frame of research, planning, and management nee to shift from short term planning (five years or less) to long term planning that accommodates effects of shifting mosaics created by forestry. Present patterns of habitat fragmentation are the result of short term, small scale planning (Galindo-Leal 1994). Lack of foresight forecloses future options. New tools such as satellite imagery, Geographic Information Systems, and decision-support systems are needed to develop alternative scenarios resulting from planning processes (Hansen et al. 1993; Daust and Bunnell 1992, 1994).

\section{Interagency Coordination and Public Communication}

Because of the large scales involved in ecosystem management, agencies have to plan and manage in close coordination with one another. The approach implies a process of learning to man- 
age the land at multiple spatial scales. It implies integration of interdisciplinary teams of land management agencies and the development of solutions to fit local conditions (Salwasser 1992; CSP 1994, CSP 1995b; Grumbine 1994). Ecosystem management requires an approach which integrates research, planning and management (Kessler et al. 1992; Joyce 1992; Salwasser 1992; Slocombe 1993). Because the targets are socially derived, involve trade-offs, and are over long time periods, public sharing of the goal setting becomes very important (Gerlach and Bengston 1994).

\section{Opportunities}

Canada has unique barriers to developing applied research potential (Bunnell and Dupuis 1994) and has a unique need for developing that potential as it relates to the issues surrounding ecosystem management. No other western nation is as dependent on natural resources in its goal of a positive balance of trade. Similarly, no other western nation is as vulnerable to the potential vagaries of "green consumerism" or ill-informed certification programs. Fortunately, the nation also enjoys some opportunities absent elsewhere. Canada, for example, has a long and pioneering history of ecological land classification which has clear application to ecosystem management (Lewis et al. 1994; Pojar et al. 1994). Other opportunities have been reviewed by Bunnell et al. (1994) and Bunnell and Dupuis (1994).

Briefly, these opportunities derive from a low people-toresources ratio, small amount of federal legislation relating to forest resources, and large degree of public ownership of forest land. The first two provide flexibility. The small people-toresources means there are still areas where old growth remains and where diverse systems of large carnivores and herbivores are still functional. Protected area strategies coupled with appropriate zoning of forestry of different intensity are possible with less cost than is true elsewhere. The lack of a large body of federal legislation means that provincial acts can be tailored to regional conditions; federal acts often lose flexibility or effectiveness in their necessary generality. There is greater opportunity for managers and researchers to develop effective solutions to resource conflicts and less propensity for these to be resolved by lawyers and judges than is true elsewhere (Bunnell and Dupuis 1994). The large, contiguous tracts of publicly owned land offer three additional advantages.

First, public ownership permits governments to enact broad policies that would be impeded by large private ownership, such as protected areas strategies. Such strategies are clearly part of obligations within the Convention on Biological Diversity and, once in place, provide known boundaries around which ecosystem management might be pursued. Second, public ownership permits management actions and planning at the broad regional level where natural units, such as watersheds, are not an intermingled mosaic of public and private land. Some objects of ecosystem management (e.g. biodiversity) require planning and management over large units (Bunnell 1992). Third, public ownership facilitates large, landscape-level experiments on major questions within ecosystem management (Schmiegelow and Hannon 1993; Bunnell et al. 1994). There are fewer physical barriers to attempting adaptive management than is true elsewhere.

Ecosystem management is still an evolving concept. We believe that it provides an improved framework to investigate, manage, and relate to nature. Because it is evolving, resource professionals have significant opportunities to inform and shape its direction.

\section{References}

Booth, D.L., D.W.K. Boulter, D.J. Neave, A.A. Rotherham and D.A. Welsh. 1993. Natural forest landscape management. For. Chron. 69: 141-145.

Bourgeron, P.S. and M.E. Jensen. 1994. An overview of ecological principles for ecosystem management. pp. 45-57 In M.E. Jensen and P.S. Bourgeron (Eds.) Volume II: Ecosystem management: principles and applications. USDA For. Serv., Pac. Northwest For. and Range Exp. Stn. Portland, Oregon. Gen. Tech. Rep. PNW-GTR-318. Boyle, T.J.B. 1992. International convention on climate change and biodiversity. For. Chron. 68: 578-579.

Bunnell, F. 1992. De mo'beta blues: coping with the landscape. pp. 45-58 In: Proceedings of the Seminar in Integrated Resource Management. Information Rept. M-X-183E/F, For. Can., Fredericton, NB.

Bunnell, F. 1995a. Toto, this isn't Kansas: changes in integrated forest management. Keynote Address. in Model Forest Network Workshop on Integrated Forest Management, October 3-5, 1994, Fundy Model Forest, Sussex, New Brunswick, Canada. (in press).

Bunnell, F. 1995b. Forest-dwelling vertebrate faunas and natural fire regimes in British Columbia: patterns and implications for conservation. Cons. Biol. Vol. 9, No. 3, June.

Bunnell, F. and L. Dupuis. 1994. Canadian-based literature: implications to conservation and management. Ecoscience 1: 87-92.

Bunnell, F. and L.L. Kremsater. 1990. Sustaining wildlife in managed forests. Northwest Environ. J. 6: 243-269.

Bunnell, F. and L.L. Kremsater. 1994. Tactics for maintaining biodiversity in forested ecosystems. In: I. Thompson (Ed.) Proc. XXI Intl. Union Game Biologists Congress. Vol. 1: 62-72.

Bunnell, F., C. Galindo-Leal and A. Chan-McLeod. 1994. From wildlife management to Conservation Biology: a Canadian perspective. International Wildlife Management Congress. (in press). Bunnell, F.L., D.K. Daust, W. Klenner, L.L. Kremsater and R. McCann. 1991. Managing for biodiversity in forested ecosystems. Report to the Forest Sector of the Old-Growth Strategy. 93 pp.

Burton, P.J., A.C. Balisky, L.P. Coward, S.G. Cumming and D.D. Kneeshaw. 1992. The value of managing for biodiversity. For. Chron. 68: 225-237.

Carey, A.B. 1985. A summary of the scientific basis for Spotted Owl management. pp. 100-114 In: R.J. Guiterrez and A.B. Carey (Eds.) Ecology and management of the Spotted Owl in the Pacific Northwest. USDA For. Serv. Pac. Northwest For. and Range Exp. Stn. Portland, Oregon. Tech. Rep. PNW-185.

Crow, T.H. 1990. Conservation biology and landscape ecology: new perspectives for resource managers. pp. 47-54. Prc. 1990 Soc. Amer. For. Convention, Bethesda, MD.

CSP Scientific Panel for Sustainable Forest Practices in Clayoquot Sound. 1994. Progress Report 2: Review of current Forest Practice Standards in Clayoquot Sound. Secretariat, Cortex Consultants Inc., Victoria, BC.

CSP Scientific Panel for Sustainable Forest Practices in Clayoquot Sound. 1995b. Sustainable ecosystem management in Clayoquot Sound. Planning and practices. Secretariat, Cortex Consultants Inc., Victoria, BC.

Daust, D.K. and F. Bunnell. 1992. Predicting diversity on forest land in British Columbia. Northwest Environ. J. 8: 199-200.

Daust, D.K. and F. Bunnell. 1994. Geographic information systems and forest wildlife: recent developments and future prospects. Proc. XXI Intl. Union Game Biologists Congress. vol. 1: 348-356.

FEMAT [Forest Ecosystem Management Assessment Team] Report. 1993. Forest Ecosystem Management: an ecological, economic, and social assessment. USDA (For. Serv.), USDI (Fish and Wildlife Service, National Park Service, Bureau of Land Management), EPA, USDC (National Oceanic and Atmospheric Administration, National Marine Fisheries Service).

Forsman, E.D., E.C. Meslow and H.M. Wight. 1980. Distribution and biology of the Spotted Owl in Oregon. Wildl. Monographs 87: 1-64. Franklin, J. 1994. Ecosystem Management: an overview. in press. 
In: M.S. Boyce and A.W. Haney (Eds.) Ecosystem management: concepts and methods. Yale University Press. New Havenen, CT.

Galindo-Leal, C. 1994. Transformed landscape patterns: cutting edge research. Research Links. Parks Canada, Alberta and British Columbia 2: 12-13.

Gerlach L.P. and D.N. Bengston. 1994. If ecosystem management is the solution, what's the problem? J. For. 92)8): 18-21.

Gould, B.I. Jr. 1977. Distribution of the Spotted Owl in California.

Western Birds 8: 131-146.

Grumbine, R.E. 1992. Ghost bears: exploring the biodiversity crisis. Island Press. Washington, DC. 290 pp.

Grumbine, R.E. 1994. What is ecosystem management? Cons. Biol. 8: 27-38.

Halbert, C.L. 1993. How adaptive is adaptive management? Implementing adaptive management in Washington State and British Columbia. Rev. Fisheries Sci. 1: 261-283.

Hansen, A.J., S.L. Garman, B. Marks and D.L. Urban. 1993. An approach for managing vertebrate diversity across multiple-use landscapes. Ecol. Appl. 3: 481-496.

Hunter, M., Jr. 1993. Managing biodiversity in forest at large spatial and temporal scales. pp. 102-108 In: D.H. Kuhnke (Ed.) Birds in the boreal forest: proceedings of a workshop held March 10-12, 1992, Prince Albert, Saskatchewan. For. Can. Northwest Reg., For. Cent., Edmonton, AB.

Jensen, M.E. and R. Everett. 1994. An overview of ecosystem management principles. pp. 6-15 In: M.E. Jensen and P.S. Bourgeron (Eds.) Volume II: Ecosystem management: principles and applications. USDA For. Serv., Pac. Northwest For. and Range Exp. Stn. Portland, Oregon. Gen. Tech. Rep. PNW-GTR-318.

Johnson, D. and J.K. Agee. 1988. Introduction to ecosystem management. pp. 3-14 In: J.K. Agee and D.R. Johnson (Eds.) Ecosystem management for parks and wilderness. University of Washington Press. Seattle, WA.

Johnston, B.E. 1993. Forestry and UNCED '92: a foundation for the future. For. Chron. 69: 539-544.

Joyce, L. 1992. Ecosystem Management workgroup findings. pp. 32-34 In E.T. Bartlett and J.R. Jones (Eds.) Rocky Mountain New Perspectives: Proceedings of a regional workshop. USDA For. Serv., Gen. Tech. Report RM-220.

Kaufmann, M.R., R.T. Graham, D.A. Boyce, W.H. Moir, L. Perry, R.T. Reynolds, R.L. Bassett, P. Mehlhop, C.B. Edminster, W.M. Block and P.S. Corn. 1994. An ecological basis for ecosystem management. USDA For. Serv. Rocky Mountain For. and Range Stat. and Southwestern Region. Gen. Tech. Report. (in press).

Kessler, W.B. 1992. A parable of paradigms. J. For. 90: 18-20

Kessler, W.B., H. Salwasser, C.W. Cartwright, Jr. and J.A. Caplan. 1992. New perspectives for sustainable natural resource management. Ecol. Appl. 2: 221-225.

Kuhn, T. 1970. The structure of scientific revolutions. 2nd. ed. University of Chicago Press, Chicago, IL. 210 p.

Lee, K.N. 1993. Compass and gyroscope. Integrating science and politics for the environment. Island Press, Washington, DC. 243 p.

Lewis, K., A. MacKinnon and D. Hamilton. 1994. Protected areas planning in British Columbia. pp. 17-54 In: M.H. Huff, S.E. McDonald, and H. Gucinski (Tech. Coord.). Applications of ecosystem management. Proc. of Third Habitat Futures Workshop. USDA. Forest Service, Gen. Tech. Rept. PNW-GTR-336, Portland, OR.
Maini, J.S. 1992. Sustainable development of forests. Unasylva 43: 3-8. Nelson, J., J.D. Brodie and J. Sessions. 1991. Integrating short-term, area-based logging plans with long-term harvest schedules. For. Sci. 37: 101-122.

Nelson, J.D. and S.T. Finn. 1991. The influence of cut-block size and adjacency rules on harvest levels and road networks. Can. J. For. Res. 21: 595-600.

Noss, R. 1992. Issues of scale in conservation biology. pp. 239-252 In: P.L. Fiedler and S.K. Jain (Eds.) Conservation biology: the theory and practice of nature conservation, preservation and management. Chapman and Hall, New York and London.

O'Donnell, J. 1990. Word gloss. Institute of Public Administration, Dublin, Ireland. 290 pp.

Pojar, J., N. Diaz, D. Steventon, D. Apostol and K. Mellen. 1994. Biodiversity planning and forest management at the landscape scale. pp. 55-70 In: M.H. Huff, S.E. McDonald and H. Gucinski (tech. Coord.). Applications of ecosystem management. Proc. of Third Habitat Futures Workshop. USDA, Forest Service, Gen. Tech. Rept. PNW-GTR-366, Portland, OR.

Rowe, J.S. 1994. A new paradigm for forestry. For. Chron. 70: 565-568.

Ruggiero, L.F. 1991. Wildlife habitat relationships and viable populations. pp. 443-445 In: Ruggiero et al. (Eds.) Wildlife and vegetation of unmanaged Douglas-Fir Forests. USDA, For. Serv., Pac. Northwest For. and Range Exp. Stn. Portland, Oregon. Gen. Tech. Rep. 285.

Salwasser, H. 1988. Managing ecosystems for viable populations of vertebrates: a focus for biodiversity. pp. 87-104. In: J.K. Agee and D.R. Johnson (Eds.) Ecosystem management for parks and wilderness. University of Washington Press., Seattle, WA.

Salwasser, H. 1992. The challenge of new perspectives. pp. 3-7 In: E.T. Bartlett and J.R. Jones (Eds.) Rocky Mountain New Perspectives: Proceedings of a regional workshop; July 8-10; Fort Collins, Co. USDA For. Serv., Rocky Mountain For. and Range Exp. Stn. Fort Collins, Co. Gen. Tech. Report RM-220.

Schmiegelow, F.K.A. and S.J. Hannon. 1993. Adaptive management, adaptive science, and the effects of forest fragmentation on boreal birds in northern Alberta. Trans North Am. Wildl. and Nat. Resour. Conf. 58: 584-598.

Slocombe, D.S. 1993. Implementing ecosystem-based management. BioScience 43: 612-622.

Waring, R.H. 1989. Ecosystems: fluxes of matter and energy. pp. 17-41. In: J.M. Cherrett, (Ed.) Ecological concepts: the contribution of ecology to an understanding if the natural world. Blackwell Scientific Publications, Oxford, U.K.

White, P.S. and S.T.A. Pickett. 1985. Natural disturbance and patch dynamics: an introduction. pp. 3-13 In S.T.A. Pickett and P.S. White (Eds.) The ecology of natural disturbance and patch dynamics. Academic Press, London, U.K.

Wiens, J.A. 1989. The ecology of bird communities. Vol I and II. Cambridge University Press, Cambridge, U.K.

Wilcove, D. 1989. Of owls and ancient forests. pp. 76-95 In E.A. Norse (Ed.) Ancient forests of the Pacific Northwest. Island Press. Washington, DC.

Williams, B.L. and B.G. Marcot. 1991. Use of biodiversity indicators for analyzing and managing forest landscapes. Trans. 56th N.A. Wildl. \& Nat. Res. Conf. pp. 613-627. 